\title{
A Morphological Study on Endemic Erodium pelargoniiflorum (Geraniaceae), from Turkey
}

\author{
Dilek Oskay $^{1 *}$, Ersin Minareci ${ }^{1}$, Emine Alçıtepe ${ }^{2}$ \\ ${ }^{1}$ Department of Biology, Faculty of Science and Arts, Manisa Celal Bayar University, Campus of Şehit Prof. Dr. \\ İlhan Varank, 45140, Manisa, Turkey \\ ${ }^{2}$ Department of Olives and Olive Business Technology, Akhisar Vocational School, Manisa Celal Bayar University, \\ Manisa, Turkey \\ *dilek.oskay@cbu.edu.tr
}

Received: 1 May 2018

Accepted: 18 June 2018

DOI: $10.18466 /$ cbayarfbe.429797

\begin{abstract}
Erodium pelargoniiflorum is an endemic species from Turkey and limited information about the native species. Morphological characteristics are investigated on the specimens collected from natural populations from Isparta. Almost all morphological characteristics are expanded and some morphological characteristics are firstly determined in this study. Flower morphology was identified in detail. Fruit is long-beaked 4.3-4.5 $\mathrm{cm}$, stout and adpressed-pilose and sparsely glandular hairy. Mericarp morphology of fruit characters was investigated for importance in taxonomical studies. Also, the mericarp micromorphology and seed micromorphology were determinated. Mericarp size 7-8 mm, mericarps have 2 apical shallow pits (foveoles). Mericarp surface ornamentation is foveate with crowded longer and shorter bristles and short glandular hairy throughout surface but glandular hairy at the start of the pit are longer. Mericarp pit is crowded long glandular hairs. Seed size is $4-5 \times 1.5-2 \mathrm{~mm}$, seed type is narrowly ovate, seed surface is ruminate.
\end{abstract}

Keywords: Endemic, Erodium pelargoniiflorum, Micromorphology, Morphology, Turkey.

\section{Introduction}

Erodium L'Herit is represented many species on all continents except Antarctica and the Mediterranean region is the largest center of diversity of the genus [1]. This region has 63 species (74 taxa) according to Fiz et al. [1] while has much more species up to 87 for now, with taxa in Turkey, according to Davis [2,3], Oskay [4]. The genus Erodium shows distribution a total of 30 taxa with 25 species and subspecies in Turkey, and 16 of these taxa are endemic [2-6].

Erodium pelargoniiflorum Boiss \& Heldr. is endemic species known from a few restricted region in Turkey. This species is a very distinctive species according to other Erodium species in Turkey but there is limited information about the native species. There are some investigations on its taxonomy and petal features from cultivated in The Royal Botanical Garden of Madrid Herbarium (MA) from seeds collected from Ermenek in Turkey $[1,7]$.

The present study aimed to expanded morphological descriptions of this endemic species, including its detailed floral features. Also, mericarp and seed surface were investigated and Scanning Electron Microscopy (SEM) photos were given in this study.

\section{Material and Methods}

E. pelargoniiflorum was collected natural populations from Kuzca-Totabeli in Isparta, 1400-1500 m, during the fieldwork in July, 2011. The specimens are dried according to standard herbarium techniques and stored at Herbarium of the Manisa Celal Bayar University Science and Arts Faculty. For the morphological studies dried samples were used. Measurements of all specific characters and fruit with seed are determined on at least twenty times. Photographs about general view of the individuals, flower parts and fruit added the study. Fruit and seed are also directly placed on prepared stubs and covered with gold for micromorphological features by SEM. Photographs are taken with Jeol JSM 6060. Fruit terminology follows in literature [1-3]. Seeds terminology follows in literature [8].

\section{Results \\ 3.1. Morphology of Vegetative Parts}

E. pelargoniiflorum is monoecious saxatile perennial plants with branched woody caudex clothed in old stipules and black colored (Figure 1). Stems are ascending, 12-50 cm, and simple or scarcely branched with short and long glandular hairy and shaggily pilose. 
Basal leaves are ovate, shortly 3-5 lobed, up to $9 \times 13 \mathrm{~cm}$, crenate or crenate-dentate, long and short glandular hairy and sparsely hirsute with up to $23 \mathrm{~cm}$ petiole, long and short glandular hairy. Leaf size and petiole length are steadily declining over the stem. Upper cauline leaves usually two number and opposite, more acutely toothed, long and short glandular hairy.
Stems bearing 2-5 peduncules. Peduncules are $8-15 \mathrm{~cm}$, shaggily pilose and long and short glandular hairy. The umbel inflorescens have 6-11 flowers. Umbels multibracteate and bracts are transparent-looking and light brick color or colorless. Pedicels are very slender, to $7-10 \mathrm{~mm}$ accrescent to $33-38 \mathrm{~mm}$ in fruit, short and long glandular hairy and shaggily pilose.

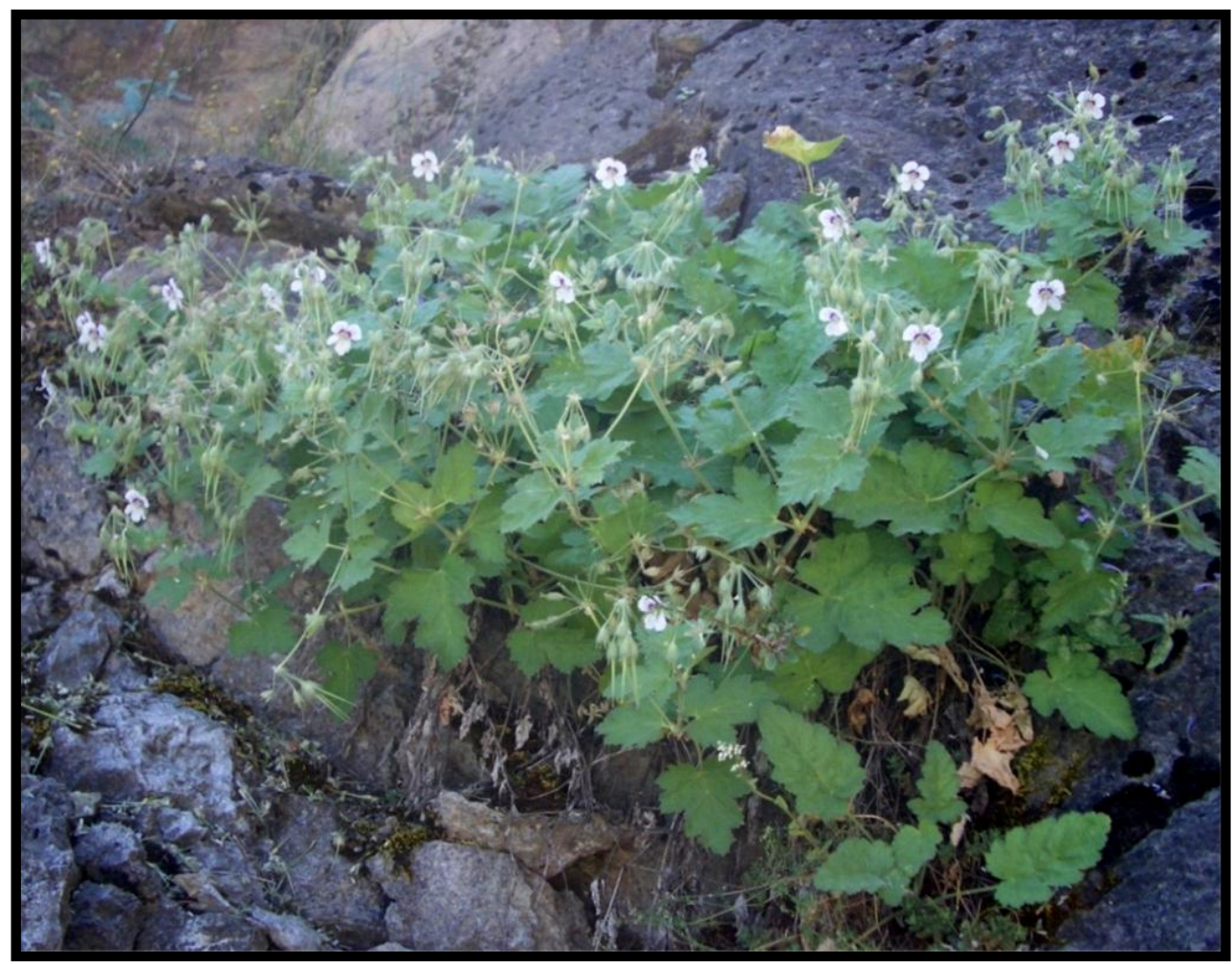

Figure 1. General appearence of Erodium pelargoniiflorum in nature.

\subsection{Morphology of Reproductive Parts \\ 3.2.1. Flower Morphology}

Flowers are zygomorphic (Figure 2). Flowers consisting of five sepals, five petals, five nectaries. Petals are \pm dimorphic, white with violet veins and two petals have dark ramified spots (a bit wider than other petals), broadly obovate, 4-9 $\times 8-12 \mathrm{~mm}$, sparsely short pilose towards base. 3 nectaries have glistening droplets arranged between petals with dark ramified spots, other 2 nectaries are seems vestigial and have very densely hirsut indumentum arranged between other petals. Five fertile stamens and five staminodes enclose the gynoecium with five carpels in flowers. Sepals appearance are transparent, sepal veins are usually green and darker than the rest of the sepal. Sepal shape is oblong-elliptic, 3-4 × 7-8 mm obtuse with $2-3 \mathrm{~mm}$ mucro, (accrescent to $4-6 \times 12 \mathrm{~mm}$ with $5 \mathrm{~mm}$ mucro in fruit). Dorsal part of sepals is covered with short and long glandular hairy. The sepals are not deciduous after the fruit formation. The ovary have five carpels and syncarpous, with each chamber having a single ovule with basal placentation. The style is terminated by five furcated light green colored stigmas. The stamens are antisepalous, introrse and versatile. Anthers are twocelled and opened longitudinally.

\subsubsection{Fruit Macro- and Micro- Morphology}

Fruit type is schizocarp and divided into five mericarps (Figure 2). Fruit is long-beaked $4.2-4.5 \mathrm{~cm}$, stout and adpressed-pilose and sparsely glandular hairy. The outer part of the style separating into 5 long awns that usually remain attached to the mericarps. Awns are spirally twisted below and rarely deciduous. Mericarp size 7-8 $\mathrm{mm}$ and light brown with whitish bristles. Mericarps have 2 apical shallow pits (foveoles) without furrow beneath. Mericarp awn is not plumose. Mericarp surface ornamentation is foveate with crowded longer and shorter bristles and short glandular hairy throughout surface but glandular hairy at the start of the pit are longer. Mericarp pit is crowded long glandular hairs (Figure 3). 


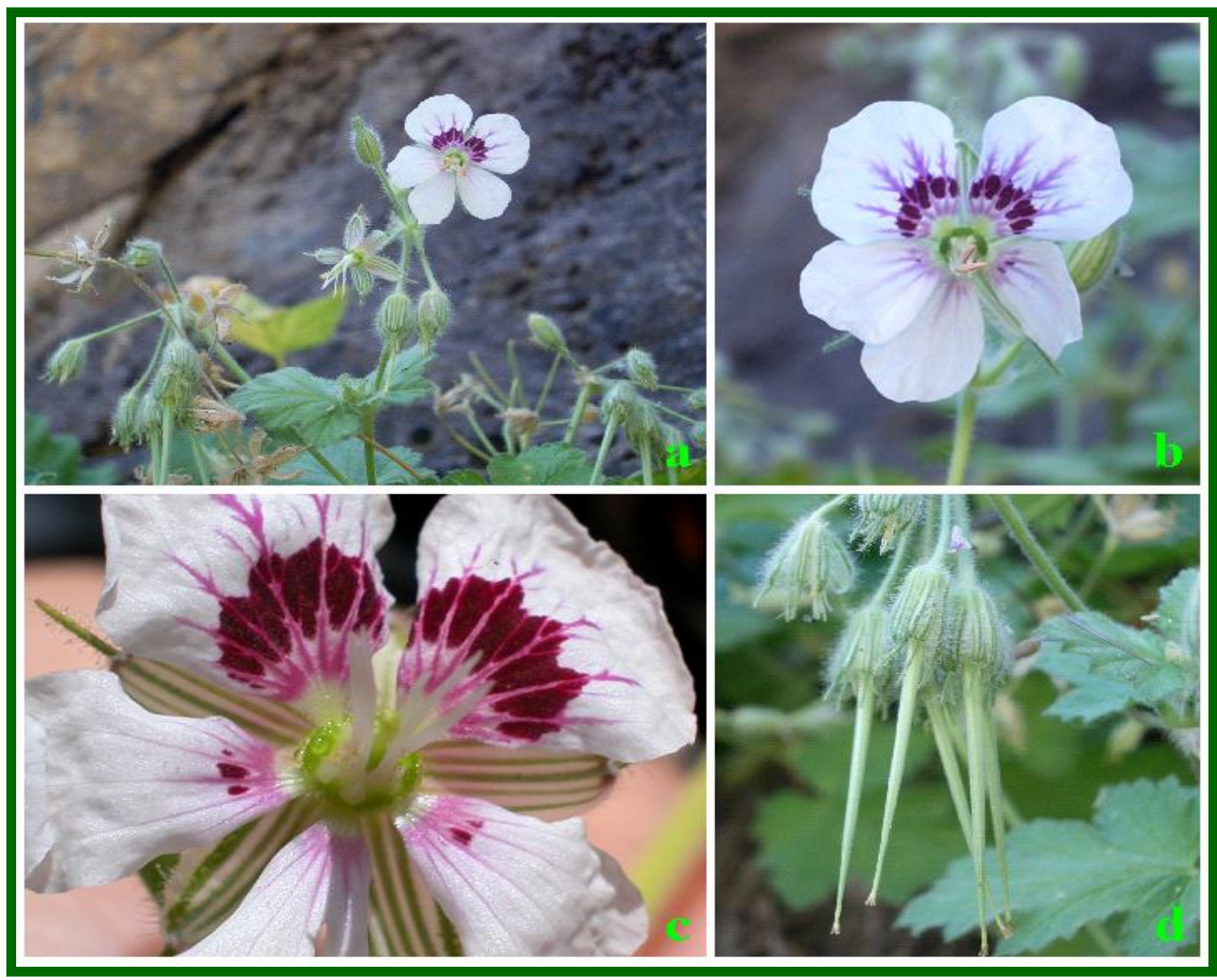

Figure 2. Reproductive parts of E. pelargoniiflorum, a- Zygomorphic flower; b- Petals with dark ramified spots and evident 3 upper nectariums; c- Glistening droplets on upper nectariums and vestigial nectariums in a flower; $\mathrm{d}-\mathrm{A}$ bit accrescent sepals and long beaked fruits.
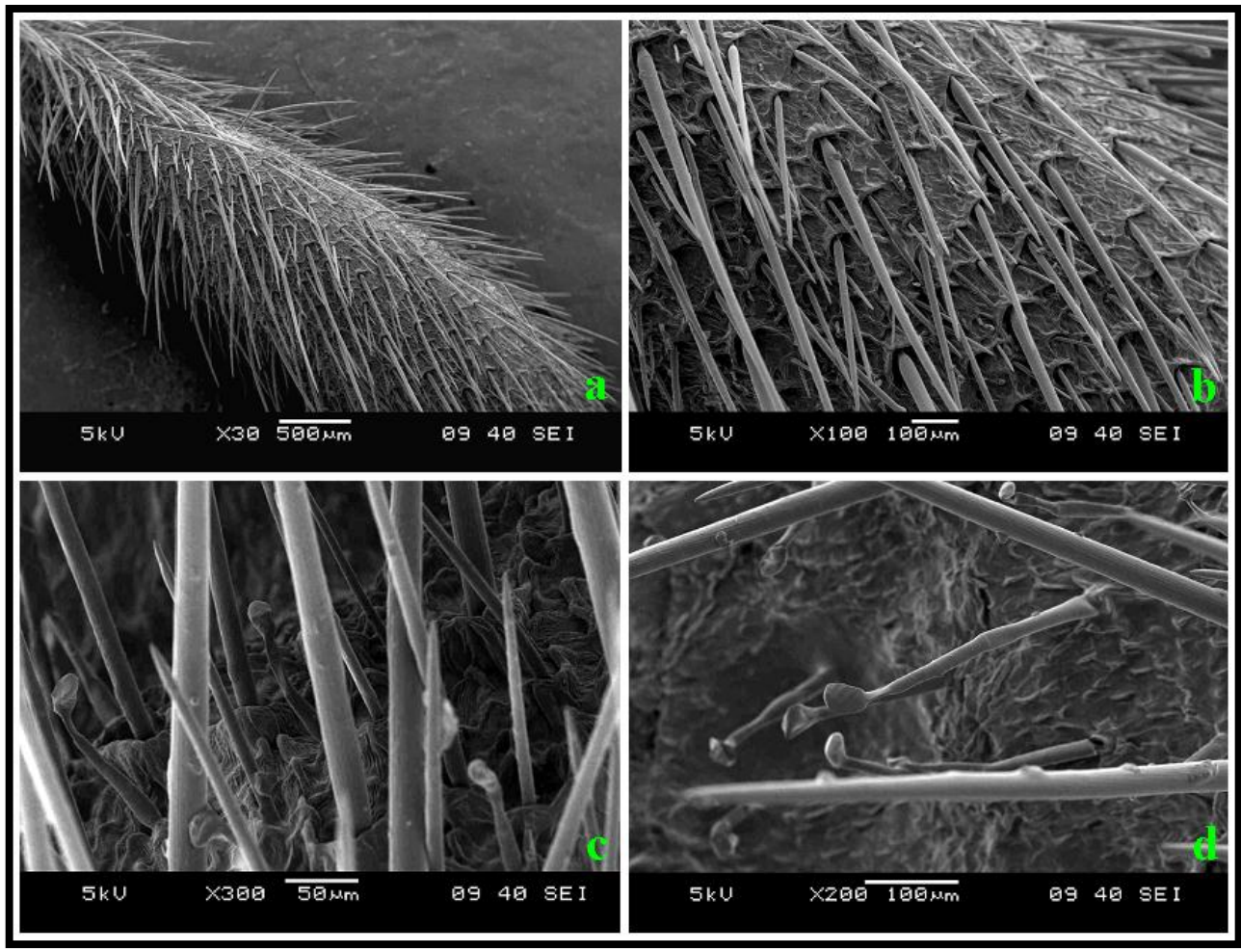

Figure 3. SEM photographs of E. pelargoniiflorum mericarps, a- A part of general appearence of mericarp surface; b- Long and short bristles; c- Glandular hairs on throughout mericarp; dMericarp pit surface ornamentation. 


\subsubsection{Seed Macro- and Micro- Morphology}

Seed color is light brown-dark green brown. Seed 4-5 $\mathrm{mm}$ long and 1.5-2 mm wide, seed type is narrowly ovate, dorsal section of seed plain, ventral section of seed slightly swollen, hilum not with recess and clearly evident. When examine SEM photographs of seed surface is determinated ruminate as follows in literature [8] (Figure 4).

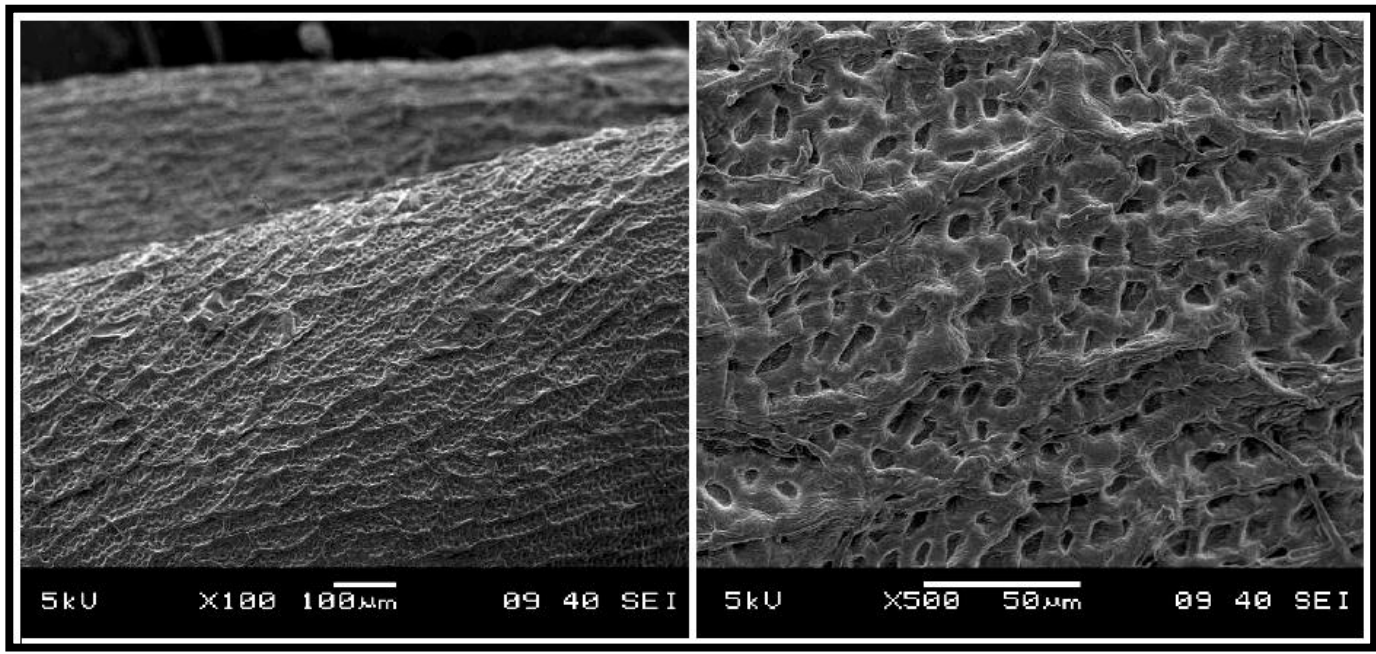

Figure 4. SEM photographs at different magnification of E. pelargoniiflorum seed surface.

\section{Discussion}

E. pelargoniiflorum endemic species to Turkey was investigated morphologically in the presented study to contribute to description and elucidate some details. Almost all morphological characteristics are expanded and some morphological characteristics are firstly determined in our study. A lot of characteristics with some exceptions were given firstly in this study because information belonging to this species was quite limited.

Knowledge about E. pelargoniiflorum are found in the two studies. One of them is the about insect attracting structures on Erodium petals (Geraniaceae) by Aldasoro et al. [7]. In this study, petal features in 75 Erodium taxa were evaluated according to the persistence, floral symmetry, spots only in the two superior petals, nectar collecting hairs on petal surface or in the claw, plain glistening hairs on the petal surface and spherical hairs filled with liquid in the claw. It was reported that floral symmetry is zygomorphic and there are spots only in the two superior petals and nectar collecting hairs on petal surface or in the claw in E. pelargoniiflorum. These information are also supported by our results.

The other study is phylogenetic relationships and evolution in Erodium based on some gene sequences by Fiz et al. [1]. In this study, a lot of data were analyzed and evaluated together about 74 Erodium taxa which spreading throughout the world. Considering our findings regarding $E$. pelargoniiflorum is compatible with this work as it understood from the morphological data matrix. Our difference is comprehensive description and contains plenty of visual information data belonging to a single species.
Mericarp morphology and micromorphology have an important place in the taxonomic point of view in Erodium. Studies related on this issue has increased in Turkey in recent years. One of these studies are two closely related taxa (E. hendrikii and E. malacoides) were compared with respect to some morphological and micromorphological characters and separated thanks to new findings by Coşkunçelebi et al. [9]. In another study, micromorphological investigations on mericarp of some annual taxa of Erodium was made by Oskay and Eş [10] who investigated mericarp micromorphology of six annual taxa distributed in Manisa and found significant differences between species.

Seed characteristics and microsculpturing of $E$. pelargoniiflorum are given in this study and this is the second documentation about seed microsculpturing in Erodium. The other study is morphological study about dioecious endemic Erodium somanum H. Peşmen [4]. When looking at the each species, in terms of seed micromorphology, it said that both species show similar properties. But other morphological characters are quite different for the two species.

In conclusion, we aimed to introduce morphological details of the endemic E. pelargoniiflorum, a perennial plant species with this study. Because, the morphological features of this endemic taxon were quite limited in Flora of Turkey [2]. Morphological and micromorphological findings and related photographs with some exceptions in this work for E. pelargoniiflorum presented the important data available in the literature. 


\section{References}

1. Fiz, O, Vargas, P, Alarcon, M.L, Aldasoro, J.J, Phylogenetic Relationships and Evolution in Erodium (Geraniaceae) Based on trnL-trnF Sequences, Systematic Botany, 2006, 31(4), 739-763.

2. Davis, P.H, Erodium L'Hérit. In: Davis P.H (ed) Flora of Turkey and the East Aegean Islands, Vol. 2. Edinburgh University Press, Edinburgh, 1967, pp. 475-487.

3. Davis, P.H, Mill, R.R, Tan, K, Erodium L'Hérit. In: Davis, P.H, Mill, R.R, Tan, K, (eds), Flora of Turkey and the East Aegean Islands, Vol. 10 (Suppl. I). Edinburgh University Press, Edinburgh, 1988, pp. 105-106.

4. Oskay, D, A morphological study on dioecious endemic Erodium somanum H. Peşmen (Geraniaceae), critically endangered in Turkey, Acta Botanica Croatica, 2017, 76, 27-31.

5. Güner, A, Özhatay, N, Ekim, T, Başer, K. H. C, Erodium L'Hérit. In: Güner, A, Özhatay, N, Ekim, T, Başer, K. H. C, (eds), Flora of Turkey and East Eagean Islands, Vol 11 (Suppl. II). Edinburgh University Press, Edinburgh, 2000, pp.74-75.
6. Yıldırımlı, Ş, Doğru-Koca, A, A new species from Turkey, Erodium aytacii Yıldırımlı \& A. Doğru-Koca (Geraniaceae), The Herb Journal of Systematic Botany, 2004, 11, 1-6.

7. Aldasoro, J.J, Aedo, C, Navarro, C, Insect attracting structures on Erodium petals (Geraniaceae), Plant Biology, 2000, 2, 471-481.

8. Stearn, W.T, Botanical Latin, 4th edition. Publisher David \& Charles, 1996, pp. 506-507.

9. Coşkunçelebi, K, Terzioğlu, S, Karaköse, M, Güzel, M.E, Contributions to the description and molecular properties of Erodium hendrikii Alpınar (Geraniaceae), endemic to Turkey, Turkish Journal of Botany, 2012, 36, 455-461.

10. Oskay, D, Eş, Ö, Micromorphological investigations on mericarp of some annual taxa of Erodium, Celal Bayar University Journal of Science, 2015, 11, 59-68. 